\title{
Choice of Implant Surface-Feature May Affect the Viability of the Adherent Cells
}

\author{
Implant Yüzey Özelliği Seçimi Adherent Hücrelerin Canlılı̆ını Etkileyebilir
}

\author{
Gül İpek Gündoğan' ${ }^{1}$, Tayfun Cıvak² ${ }^{\text {D }}$, Cenk Kığ $^{3}$ (i) \\ 'Department of Histology and Embryology, Faculty of Medicine, Istanbul Yeni Yuzyil University, Istanbul, Turkey \\ 2Department of Oral and Maxillofacial Surgery, Faculty of Dentistry, Istanbul Yeni Yuzyil University, Istanbul, Turkey \\ ${ }^{3}$ Department of Medical Biology and Genetics, Faculty of Medicine, Istanbul Yeni Yuzyil University, Istanbul, Turkey
}

ORCID ID: G.I.G. 0000-0002-9438-6113;T.C. 0000-0002-8770-3731; C.K. 0000-0002-6318-5001

Cite this article as: Gündoğan Gl, Cıvak T, Kığ C. Choice of implant surface-feature may affect the viability of the adherent cells. Experimed 2021; 11(1): 38-44.

\begin{abstract}
Objective: In vitro evaluation of implant materials' effects on cell adhesion and viability can provide useful information for predicting implant biocompatibility. Therefore by using a simple and inexpensive method, it was aimed to investigate whether different implant surface-features might have distinct effects on the viability and adherence of the cells.
\end{abstract}

Material and Methods: Different dental implant surfaces (anodized (AN), blasted wrinkled (BW), grit/acid etched (GA), and hydroxylapatite sprayed (HB)) were tested for their possible effects on adhesion and viability of the adherent human osteoblast cells by using an agar-based in vitro technique. Viability of the cells was assessed by 3-(4,5-dimethylthiazol-2-yl)-2,5-diphenyltetrazolium bromide (MTT) assay and trypan blue staining.

Results: The rate of cell adhesion did not seem to be significantly affected by the differences in surface features of dental implants (AN:78.21 $\pm 0.52 ; B W: 78.22 \pm 0.48 ; G A: 78.44 \pm 0.85 ; H B: 77.26 \pm 0.96$ ). The surface features of the dental implants had an impact on the viability of the attached cells on the implants. Viability of the attached cells was significantly higher on AN, BW, GA surfaces when compared to the HB surface (AN: $72.28 \pm 6.04, B W: 67.02 \pm 3.47, G A$ : 85.82 \pm 5.05 , and HB: $27.98 \pm 10.47$ ).

Conclusions: In vitro findings suggests that AN, BW, GA surfaces may provide a better platform than HB surfaces to maintain the viability of bound cells.

Keywords: Biocompatible surfaces, irregular surfaces, cell adhesion potential, cell culture, dental implants

\section{öz}

Amaç: İmplant materyallerinin hücre canlılığı ve hücre adezyonu üzerindeki in vitro etkilerinin değerlendirilmesi, implantların biyo-uyumluluklarının tahmin edilmesi yönünde değerli bilgiler sağlayabilir. Bu nedenle, basit ve maliyetli olmayan bir yöntem kullanılarak, farklı yüzey özelliklerine sahip implantların hücre canlılığı ve adezyonunu etkileyip etkilemeyeceğinin araştırıması amaçlanmıştır.

Gereç ve Yöntemler: Farklı diş implant yüzeylerinin (anotlanmış (AN), patlatılmış buruşuk (BW), kum/asitle aşındırılmış (GA), püskürtülmüş hidroksi apatit yüzey (HB)) yapışma ve canlılık üzerindeki etkileri, adherent insan osteoblast hücre soyunda agar bazlı bir in vitro teknik kullanılarak karşılaştırılmıştır. Hücre canlılıklarının belirlenmesinde, 3-(4,5-dimetiltiazol-2-il)-2,5-difeniltetrazolium bromid (MTT) ve tripan mavisi boyama teknikleri uygulanmıştır.

Bulgular: Hücre adezyonunun, dental implantların yüzey özelliklerindeki farklılıklardan önemli ölçüde etkilenmediği görülmüştür

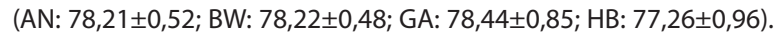
Ancak, diş implantlarının yüzey özelliklerinin, implantlara tutunan hücrelerin canlılığı üzerinde etkisi olduğu tespit edilmiştir. Tutunan hücrelerin canlııı̆ının, HB yüzeyine kıyasla AN, BW, GA yüzeylerinde anlamlı olarak daha yüksek olduğu bulunmuştur (AN: $72,28 \pm 6,04$, BW: $67,02 \pm 3,47$, GA: $85,82 \pm 5,05$ ve HB: $27,98 \pm 10,47$ ).

Sonuçlar: Çalışma kapsamında yapılan in vitro deneylerden elde edilen bulgular; AN, BW, GA yüzeylerinin adherent hücrelerin canlılığını korumaları için HB yüzeylerinden daha iyi bir platform sağlayabileceğini göstermektedir.

Anahtar Kelimeler: Biyouyumlu yüzeyler, düzensiz yüzeyler, hücre adezyon potansiyeli, hücre kültürü, dental implantlar 


\section{INTRODUCTION}

Implants are useful instruments used in a variety of clinical settings, including orthopedics and dentistry. Technology and research on implantation materials have greatly expanded in recent years. For example, titanium dental implants are routinely used for the treatment of tooth loss. The success of the operation in part depends on the reaction of the tissue to the implant. The reaction of the tissue to the implants can be divided into two stages: formation of fibrous soft tissue capsules around the implant and osseointegration (1). The fibrous tissue capsule helps biomechanical fixation, therefore the absence of this structure can lead to dental implant failure. The surface property of the biomaterial can determine the success of the osseointegration process. Various modifications can be made on dental implant surfaces to improve osseointegration.

Cell adhesion is critical for the implant's effective incorporation into bone tissue. For this reason, the use of a biocompatible surface that would not have a negative effect on proliferation, adhesion, and phenotype expression of osteoblasts is recommended (2).

The roughness and physical changes made on the biomaterial surface are known to affect the response of tissues and cells to implantation (3). The two most commonly used methods to roughen the surfaces of dental implants include etching and coating techniques. Sand-blasting and pickling methods are common practices for etching (3). The most commonly used techniques in the coating method are bioactive calcium phosphate ceramic coatings and titanium plasma spray coatings (4). Titanium plasma-spraying (TPS) and hydroxyapatite (HA) coatings are frequently used as coating materials. Microporous or nanoporous surfaces can also be produced with anodization of titanium at the high electric current or another way to roughen titanium dental implants is to use heavy acids (e.g., $\mathrm{HF}_{2} \mathrm{H}_{2} \mathrm{SO}_{4}, \mathrm{HNO}_{3}, \mathrm{H}_{3} \mathrm{PO}_{4}$ ) (1).

There are several different experimental methods to evaluate adhesion competence. For example, the "washing" technique makes identifying adherent cells with a short lifespan simple, allowing cells detached from the implant's surface to be counted (5). Also, cell separation technology, micropipette suction technology, the measurement method of force spectroscopy, force probe for biofilms, optical tweezers, rotating disk method are available techniques that can be used (6). These methods, however, are not readily available in every laboratory, and they may not be successful in determining the rate of cell proliferation and adhesion on irregular surfaces like implant grooves.

Evaluation of the in vitro effects of implant materials offers many advantages on the prediction of the success and biocompatibility of the implants. In this respect, it is important to investigate the effects of materials on cell viability as well as the adherence of the cells. Inexpensive, simple, rapid, and accurate techniques can provide convenience for researchers in terms of the pre-evaluation of the materials. In this study, the effects of different implant surfaces were tested on the adhesion and proliferation rate of human osteoblasts. A modified version of the wash-of process, which was recently defined, was used for this purpose (7). Using this inexpensive and simple in vitro technique, the impact of dental implants with the anodized surface (AN), blasted wrinkled surface (BW), grit-blasted/acid-etched surface (GA), or hydroxyl apatite-blasted surface (HB) features were compared.

\section{MATERIALS AND METHODS}

\section{Cell culture}

The human osteoblast (HOB) cell line (406-05F, Sigma-Aldrich) was cultivated in high glucose Dulbecco's Modified Eagle's medium (5546 DMEM-Sigma-Aldrich) and 10\% fetal bovine serum (heat-inactivated., S1810-500, Biowest), 1\% 2mM I-glutamine (Biological Industries, BI03-020-1B), and P/S (50 U/mL streptomycin and $50 \mathrm{~g} / \mathrm{mL}$ penicillin; 03-031-1B, Biological Industries) was added to the mix (complete medium). $1.5 \times 10^{6}$ cells were seeded into $10 \mathrm{~cm}$ plates. For 72 hours, at $37^{\circ} \mathrm{C}$, the plates were incubated with $5 \% \mathrm{CO}_{2}$ before being split. 3-(4,5-dimethylthiazol-2-yl)-2,5-diphenyltetrazolium bromide (MTT) and trypan blue assays were performed using trypsinized cells seeded in 96-well flat-bottom culture plates.

\section{Preparation of implants and the internal control}

Agar-coated, chromium-plated metal screws with similar dimensions $(4 \times 15 \mathrm{~mm})$ were used as an internal control. Agar-coated screws served as a platform to eliminate the non-specific binding artifacts that may arise due to inadequate rinsing or as a result of clumps that got stuck between the grooves. All the dental implants were compared against this internal control. Information about the implants with different surface features used in the study is given in Table 1. Dental

Table 1. Dental implants with different surface features.

\begin{tabular}{|c|c|c|c|c|}
\hline Surface feature & Abbreviation & Brand model & Dimensions & Lot number \\
\hline Anodized surface implants & AN & $\begin{array}{l}\text { Nobel Biocare }{ }^{\mathrm{TM}} \text { NobelParallel } \\
\text { Conical Connection RP }\end{array}$ & $4.3 \times 15.0 \mathrm{~mm}$ & 12103733 \\
\hline Hydroxyl apatite-blasted surface implants & $\mathrm{HB}$ & Arrow $^{T M}-C 4014 S$ & $4.0 \times 14.0 \mathrm{~mm}$ & W5H27BY \\
\hline $\begin{array}{l}\text { Blasted wrinkled surface implants } \\
\text { (Sandblasted) }\end{array}$ & BW & $\begin{array}{l}\text { Dentegris }{ }^{\mathrm{TM}} \\
\text { 45014-SL SL-Tapered }\end{array}$ & $4.5 \times 14.5 \mathrm{~mm}$ & 17042708 \\
\hline $\begin{array}{l}\text { Grit-blasted/acid-etched surface dental } \\
\text { implants (Ca and P low impregnation) }\end{array}$ & GA & Ossean-Intra Lock ${ }^{\mathrm{TM}}$ & $4.0 \times 15.0 \mathrm{~mm}$ & BM110 \\
\hline
\end{tabular}


implants were provided as gamma-ray sterilized ready-to-use implants. Sterilization of the internal control metal screws was done with an autoclave. In this study, 12 implants were used. Each time new implants and screws were used for experiments. Representative images of dental implants are shown in Figure 1 a. As explained previously $(7,8)$, the internal control screws were coated with $0.2 \%$ agar (Multicell- 800-010-LG) to simulate conditions where cells cannot attach. As shown in Figure 1b, coating the metal screws with agar was performed by placing sterile screws (6-well) into the wells. $0.2 \%$ agar solution was prepared in phosphate-buffered saline (PBS) and $3 \mathrm{~mL}$ of agar solution was poured into the well and stored for 3 hours at room temperature. The wells were washed with $2 \mathrm{~mL}$ of $1 \times \mathrm{PBS}$, as described previously. (7).

\section{Agar petri dishes preparation and seeding cells}

The implants and screws at the bottom of the $10 \mathrm{~cm}$ petri dishes were stabilized with a drop of molten candle, as shown in Figure 1c. The implants and the internal control screw (with agar coating) were placed side by side in a single $10 \mathrm{~mm}$ petri dish. The implants and the internal control screw were then partially immersed in liquid agar (1.5\%), which was then allowed to solidify. Since cells can't bind to agar's surface, semi-submerged implants and agar-coated screws were the only places for cells to attach (7). Thus, non-specific binding artifacts may arise due to inadequate rinsing or as a result of clumps getting stuck between the grooves. Following that, onto the agar plate, $6 \mathrm{~mL}$ of complete medium containing $4 \times 10^{6}$ cells $/ \mathrm{mL}$ were poured, as shown in Figure 1c, unless the medium was fully covered the implants and the internal control screw. Since the cells were suspended in the medium before being inserted into the plate, it was expected that all exposed agar surfaces, implants, and screws would receive approximately equal numbers of cells. Although the implants and the agar-coated internal control screw were both located in the same plate, a side-by-side comparison was possible (7).

\section{Evaluation of the attachment performance of cells}

Following the addition of cell suspensions, the petri dishes were kept in the incubator for 24 hours $\left(37^{\circ} \mathrm{C}, 5 \% \mathrm{CO}_{2}\right)$ to enable the cells to bind along. Non-adherent cells were then washed away by rinsing the petri dish three times with washing buffer (PBS, pH 7.4) and discarding the washing buffer, leaving only the securely attached cells (7). After washing, $6 \mathrm{~mL}$ of medium was added and petri dishes were placed in the incubator and incubated for 48 hours (7).

\section{The number of detached cells' determination (DC values)}

The petri dishes were washed twice with $1 \times$ PBS buffer at the end of the 48-hour incubation period. During this period, wash buffer was collected in centrifuge tubes (and not discarded), and the detached cells (DC) were pelleted by centrifugation. Using trypan blue staining, the number of DC was determined. (7).

\section{The number of adherent cells' determination (AC values)} Next, using a sterile scalpel (SPL-90020, blade width $13 \mathrm{~mm}$, length $230 \mathrm{~mm}, 1 /$ sleeve) the agar around the implants and the internal control screw were cut. Then, the agar blocks still containing the buried implants or the internal control screw were transferred into the wells of a 6-well plate containing $1200 \mu \mathrm{L}$ of trypsin-EDTA and incubate in an incubator at $37^{\circ} \mathrm{C}$ for $5 \mathrm{~min}$ utes. Variations in the size of the cut agar block are unlikely to impact the calculation since the cells cannot bind to the agar

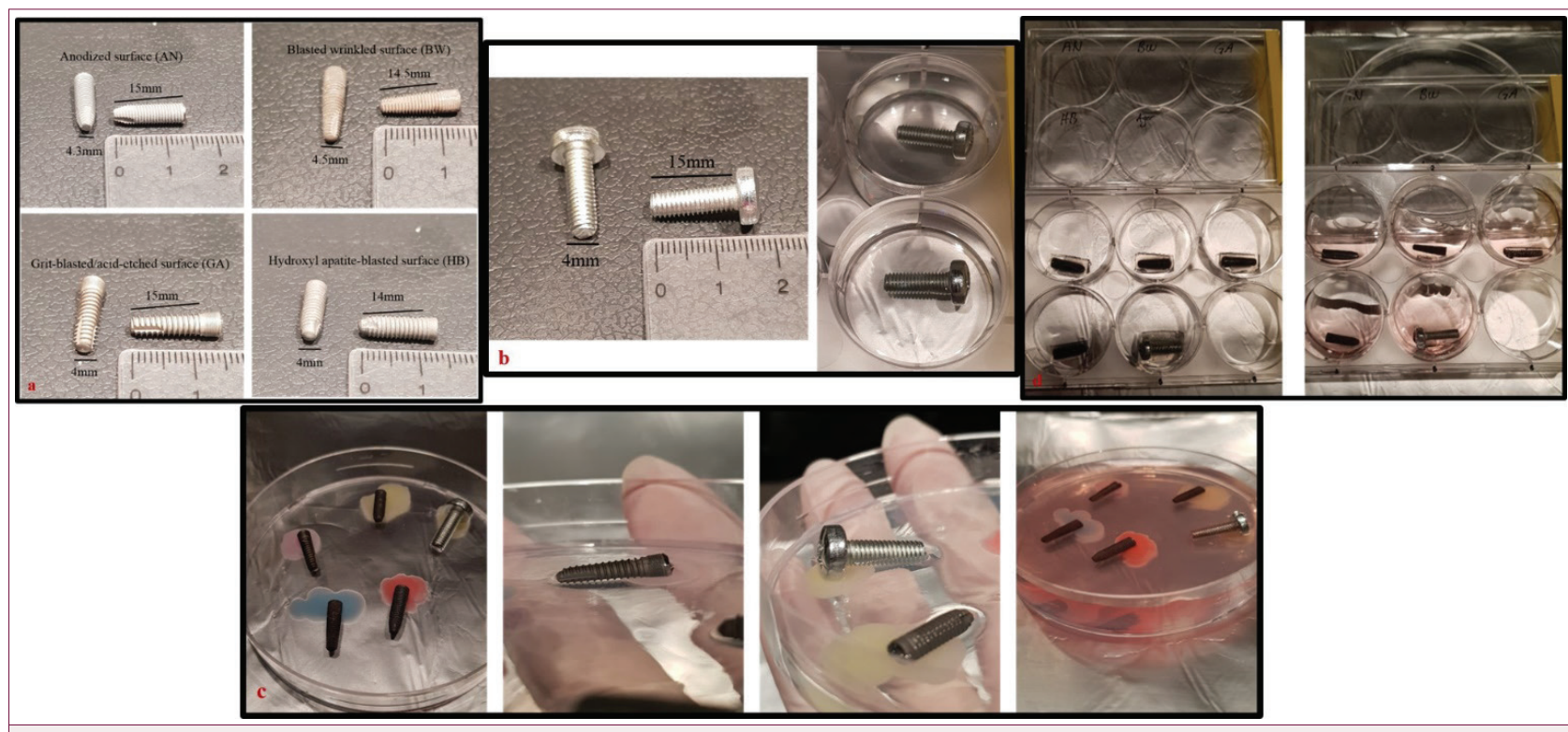

Figure 1. Representative images from different stages of the technique. a. Images of different surfaced dental implants, b. Internal control (chrome-plated screws), c. A drop of a molten candle was used to secure implants and screws, d. Detaching cells with trypsinization from implants and the internal control in 6-well plates. 
surface. Then, as shown in Figure $1 \mathrm{~d}, 2400 \mu \mathrm{L}$ of medium was added into the wells to inactivate the trypsin. Centrifugation was used to collect the cells. Then the cell pellet was resuspended in $200 \mu \mathrm{L}$ of medium. Trypan blue staining of $15 \mu \mathrm{L}$ of this cell suspension was used to assess the number of adherent cells (AC). MTT assay was performed with the remaining $185 \mu \mathrm{L}$ of cell suspension (7).

The ratio of adherent cells' determination (RCA)

The ratio of adherent cells (RCA) was determined using the formula: $\mathrm{RCA} \%=\mathrm{AC} /(\mathrm{AC}+\mathrm{DC}) * 100(7)$.

\section{Data analysis and relative RCA values calculation}

As a reference value, the RCA value obtained from the internal control screw coated with agar $\left(R C A_{\text {reference }}\right)$ was used. The delta RCA value was then calculated by subtracting the reference RCA value from the RCA values obtained from various dental implants using the formula below: $\triangle R C A_{X} \%=\left(R C A_{X} \%-\right.$

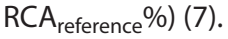

\section{Trypan blue staining}

To obtain the cell viability, 1:1 mixture of trypan blue $(0.4 \%)$ prepared in PBS and $15 \mu \mathrm{L}$ of cell suspension was used. The number of the stained (dead) cells and unstained cells were determined within 5-10 minutes with a hemocytometer (9). ent cells. The mean absorbance value for the internal control (agar-coated screws) was accepted as $100 \%$ and used as the reference value (vACreference\%). The relative changes were calculated with the following formula: $\triangle \mathrm{vAC} \times=\left(\mathrm{vAC} \mathrm{C}_{\mathrm{x}} \%\right.$ $\left.v A C_{\text {reference }} \%\right)(7)$.

\section{Statistical analysis}

GraphPad Prism version 5.0 (San Diego, CA, USA) statistical analysis software was used. Tukey's test was used to make multiple comparisons. It was considered that $p<0.05$ was statistically significant. Analysis of variance was used to examine the groups' viability and adherence indexes. The results were expressed as averages from at least three different experiments for statistical analysis.

\section{RESULTS}

\section{Baseline settings for evaluation of cell adherence}

When compared to dental implants with different surface features, the data obtained from the agar-coated internal control screws clearly showed that HOB cell attachment on the agar-coated internal control screws was limited (Table 2). As a reference value, the mean RCA value obtained from the agar-coated screws ( $\left.R C A_{\text {reference }} \%: 39.46\right)$ was used. Table 2 shows the RCA values obtained from three separate experiments.

Table 2. RCA\% values obtained from three independent experiments.

RCA\% VALUES FOR DENTAL IMPLANTS WITH DIFFERENT SURFACE FEATURES

\begin{tabular}{|c|c|c|c|c|}
\hline $\mathbf{R C A}_{\mathrm{AN}} \%$ & $\mathbf{R C A}_{\mathrm{BW}} \%$ & $\mathbf{R C A}_{\mathrm{GA}} \%$ & $\mathbf{R C A}_{\mathrm{HB}} \%$ & $\mathbf{R C A}_{\text {reference }} \%$ \\
\hline 78.22 & 78.75 & 77.48 & 77.29 & 39.13 \\
\hline 78.70 & 78.00 & 79.10 & 76.30 & 36.19 \\
\hline 77.67 & 77.86 & 78.75 & 78.22 & 43.06 \\
\hline $78.21_{\mathrm{avg} \cdot}(\mathrm{n}=3)$ & 78.22 avg. $(n=3)$ & 78.44 avg. $(n=3)$ & $77.26_{\text {avg }} \cdot(n=3)$ & $39.46_{\text {avg }}(n=3)$ \\
\hline
\end{tabular}

$\mathrm{RCA} \%=\mathrm{AC} /(\mathrm{AC}+\mathrm{DC}){ }^{*} 100, \mathrm{RCA}$ : Ratio of adherent cells' determination, AC: Adherent cells, DC: Detached cells, AN: Anodized surface, BW: Blasted wrinkled surface, GA: Grit-blasted/acid-etched surface, HB: Hydroxyl apatite-blasted surface.

\section{MTT assay}

MTT test, in vitro cytotoxicity assays (cell viability assays), was carried out according to Scudiero's (10) instructions. The 96well plate was modified from the 24-well plate format. In summary, trypsinized cell pellets were suspended in $200 \mu \mathrm{L}$ complete medium and seeded into 96-well plates. For 18 hours $\left(37^{\circ} \mathrm{C}, 5 \% \mathrm{CO}_{2}\right)$, the cells were incubated. The wells were then gently rinsed with $1 \times$ PBS. Every well obtained $200 \mu \mathrm{L}$ of MTT (3580GR001, CAS: 298-93-1., Biofroxx., Lot: 5A13FBF0,) reagent $(0.5 \mathrm{mg} / \mathrm{mL})$ prepared in DMEM. MTT solution was discarded after 4 hours of incubation at dark $\left(37^{\circ} \mathrm{C}, 5 \% \mathrm{CO}_{2}\right)$, and formazan crystals were solubilized with DMSO $(200 \mu \mathrm{L} /$ well). A spectrophotometer was used to record the absorbance at 540 nm.

\section{Determining the viability of the adherent cells (vAC)}

Absorbance obtained from the MTT assay was used for comparison of the relative changes in the viability of the adher-
Relative changes in cell adhesion as a result of various surface materials

Relative changes in cell adherence ( $\triangle \mathrm{RCA} \%$ values) were calculated as explained under the material and methods section. As shown in Table 3, a comparison of the relative changes in cell

Table 3: Relative changes in cell adherence ( $\triangle R C A \%$ values).

\begin{tabular}{rrrr}
\hline Implants & $\mathbf{R C A}_{\mathbf{x}} \%$ & $\mathbf{R C A}_{\text {reference }} \%$ & $\mathbf{S R C A}_{\mathbf{x}} \%$ \\
\hline $\mathbf{A N}$ & 78.21 & 39.46 & $\mathbf{3 8 . 7 6}$ \\
\hline BW & 78.22 & 39.46 & $\mathbf{3 8 . 7 6}$ \\
\hline GA & 78.44 & 39.46 & $\mathbf{3 8 . 9 8}$ \\
\hline HB & 77.26 & 39.46 & $\mathbf{3 7 . 8 0}$ \\
\hline
\end{tabular}

The mean reference value for RCA\% was 39.46. AN: Aanodized surface, BW: Blasted wrinkled surface, GA: Grit-blasted/acid-etched surface, HB: Hydroxyl apatiteblasted surface 
adherence did not reveal a statistically significant difference between the tested surface materials.

\section{Implant surface features affect the viability of the adherent cells in vitro}

According to the material and methods section, relative changes in the viability of the attached cells ( $\triangle \mathrm{vAC} \%$ ) were calculated. As shown in Table 4, the mean viability of the attached cells (vAC\%) was significantly improved when dental implants were used instead of the agar-coated internal control.

Table 4. Mean changes in the viability of the attached cells.

\begin{tabular}{lcccl}
\hline & vAC\% & & vAC $_{\text {reference } \%}$ & $\Delta v A C \%$ \\
\hline AN & 172.3 & - & 100 & $=72.3$ \\
\hline BW & 167 & - & 100 & $=67$ \\
\hline GA & 185.8 & - & 100 & $=85.8$ \\
\hline HB & 128 & - & 100 & $=28$ \\
\hline
\end{tabular}

Interestingly, as shown in Table 4 and Figure 2, among dental implants with different surface features, significant differences in the viability of the attached cells were detected. When compared with the HB surface, implants with AN surface improved viability by 2.58 fold $\left(\triangle \mathrm{VAC}_{\mathrm{AN}} \% / \triangle \mathrm{VAC}_{\mathrm{HB}} \%\right), \mathrm{BW}$ surface improved viability by 2.39 fold $\left(\triangle \mathrm{VAC}_{\mathrm{BW}} \% / \triangle \mathrm{VAC}_{\mathrm{HB}} \%\right)$ and $\mathrm{GA}$ surface improved viability by 3.06 fold $\left(\triangle \mathrm{vAC}_{\mathrm{GA}} \% / \triangle \mathrm{vAC}_{\mathrm{HB}} \%\right)$. The lowest viability rate was detected in $\mathrm{HB}$ surfaced dental implants. Compared to all the other three implants, the vitality rate was found to be significantly decreased. Furthermore, the effect of BW and GA surfaced dental implants on the viability of the attached cells were significantly different $(p<0.0001 ; n=3)$.

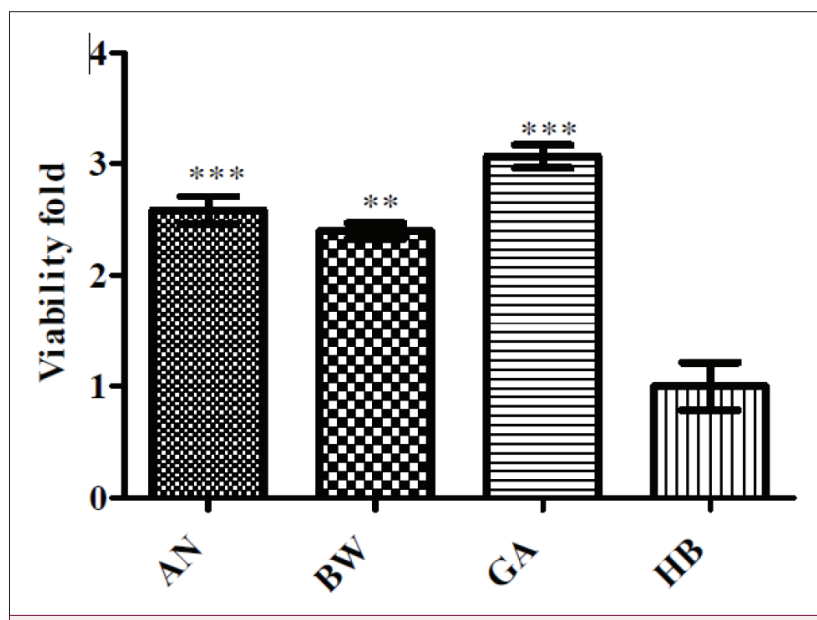

Figure 2. Implant surface features affect the viability of the attached cells.

\section{DISCUSSION}

Surface topography and the physicochemical structure of the surface materials are important factors in determining the relation between the implanted biomaterial and the bone $(11,12)$. Surface features and the geometric design of the implant structures play an important role in the success of dental implants (3). Studies have shown that modification of surface properties (e.g., AN, BW, GA, HB surfaces), can improve osteointegration. The acid etching technique, for example, has been shown to increase the surface area of implants (13). Osteoblasts contact neighboring cells and their environment through their cytoplasmic extensions. Osteointegration involves biomechanical processes where a firm connection between the bone and the implant is formed (14). Osteoprogenitor cells migrate to the implant site and differentiate into osteoblasts and provide bone formation $(15,16)$. Providing suitable surfaces for attachment of the cells and sustaining the viability of the attached cells is crucial for a successful implant operation. Therefore, the question has arisen whether the different surface features of the implants will affect the cell efficiency and/or attachment viability of the attached cells. To address this question, the effects of different dental implant surfaces (AN, BW, GA, HB) on the adhesion and viability of the attached cells were compared. The effects of the surface properties of dental implants on cell behavior had previously been studied by other groups using model systems (such as titanium discs) to simulate the surface of the implants (17-19). The titanium surface treatment, according to Arcelli et al. (20), had a direct genetic effect on osteoblasts, inducing multiple bone-related genes. On the other hand, Kieswetter et al. (21) found that cell proliferation was inversely related to surface roughness. Similarly, Lauer et al. (22) did not report any differences in osteoblast adhesion and growth on different textured titanium surfaces. In this study, the osteoblast cells were used to determine the in vitro effects of these implants. A modified version of the washing technique, recently defined by Gundogan (7), was used to see how different surface features affected cell attachment and viability. In this context, the impact of dental implants with the AN, BW, $\mathrm{GA}$, or HB surfaces features were investigated. When compared to the internal control group, cell attachment rate was significantly improved on the modified surfaces. However, there was no statistically significant difference in the rates of cell attachment when AN, BW, GA, or HB surfaces were compared (Table 3). Interestingly, it has been shown that surface features of the dental implants can affect the viability of the attached cells on the implants. Cell viability was significantly enhanced on the AN, BW, GA surfaces when compared to the HB surface (Table 4 and Figure 2).

Other researchers have examined the physiological conditions of cells using different methods for a detailed and comprehensive investigation. Conserva et al. (23) evaluated osteoblast adhesion and proliferation with qualitative scanning electron microscopy (SEM) analysis. According to Conserva et al. study (23), the SaOS-2 cells spread more rapidly on sandblasted surfaces. They have shown that cells had proliferated 
and exhibited a flat morphology after 24 hours of growth. They revealed that the most significant cell flattening was on the grit-blasted/acid-etched surface. Also, they indicated that the grit-blasted/acid-etched surface showed a greater number of SaOS-2 and MSC cells than the sandblasted surface at both 3rd and 7th days of growth, with a significant $(p<0.05)$ difference between the two surfaces (23). Contrary to the technique applied in this study, they did not stabilize the implants in the study of Conserva et al. (23) and achieved results with the base of cell lysis by not separating the cells from the implant surfaces. The implants were submerged in the cell suspension throughout the incubation wells at the same time. The implants were gently removed from plates after the incubation time and washed. The findings of Conserva et al., (23), are consistent with the study's adherence and viability results. The GA sample was also superior in this study compared to the BW sample. Both dual acid-etched and alumina-blasted surfaced (Intra-Lock) and P and Ca low impregnation (Ossean-Intra-Lock) surfaced implants provide a suitable substrate for SaOS-2 human osteoblast adhesion and development, according to Bucci-Sabattini et al. (24). Per the Bucci-Sabattini et al. (24), the MTT test for the quantitative proliferation of SaOS-2 revealed a similar proliferation rate on both surfaces with no significant difference. Quantification of alkaline phosphatase (ALP) specific activity in the SaOS-2 cell line, on the other hand, was substantially higher for the Ossean surface at all times (24). Although it is not the same cell line, Bucci-Sabattini et al.'s study (24) also support the findings of this research.

Data from previous studies (in vitro or in vivo) also suggest that GA surfaces may exhibit superior features. For example, Sammons et al. (25) showed that, compared with plasma-sprayed, acid-etched, grit-blasted, anodized, and machined surfaces the combined surface of grit blasting and acid etching induce a substantial increase in cell spreading rates. An in vivo test on dogs found that, compared with titanium plasma-sprayed surfaces, implants with grit-blasted and acid-etched surfaces can be immediately placed into the damaged periodontal area, and their performance is slightly better (26). An experimental study again in dogs evaluated the grit-blasted/acid-etched bio-ceramic and dual acid-etched implant surfaces histomorphometrically (27). When comparing the grit-blasted/acid-etched bio-ceramic implant surface to the dual acid-etched implant surface, the grit-blasted/acid-etched bio-ceramic implant surface had increasing rates of the bone organization along the perimeter, according to Marin et al. (27).

Bone cell interactions with smooth titanium, titanium plasma-sprayed, titanium dioxide-blasted, and hydroxyapatite plasma-sprayed implants were compared by Lumbikanonda \& Sammons (28). The suspended neonatal rat osteoblasts lasted for 20 minutes, and the attached cells were classified with SEM according to the stage of attachment (28). Lumbikanonda \& Sammons (28) revealed that the cells spread the fastest on titanium plasma-sprayed implants. It was shown that the completely dispersed cells on the smooth titanium implant adhered tightly to the surface, while on the titanium dioxide sandblasted surface, they did not adapt to surface irregularities. In contrast to the hydroxyapatite-coated implants, cells adhere closely only to smooth areas (28). In line with the results of this study, the cell viability was significantly higher on the other surfaces compared to the HB surface.

In agreement with the previously published data, the in vitro findings of this study implies that AN, BW, GA surfaces may present a more suitable platform to maintain the viability of bound cells when compared with the HB surfaces. The study findings also show that these in vitro evaluations can be performed using an inexpensive and simple agar-based method.

Although reproducible and solid data have been provided to support the findings, insight into the underlying molecular mechanisms and pathways has not be provided due to the lack of molecular techniques. Future studies may be designed to investigate the genes or proteins which may be involved in this differential response of HOB cells to different surface materials.

\section{CONCLUSION}

The differential features of commercially available dental implants may affect the viability of the attached cells rather than the rate of cell attachment. The results related to cell viability or adherence can be obtained accurately with an inexpensive and simple agar-based method. It has been showed that AN, BW, GA surfaces can provide a better platform than HB surfaces to maintain the viability of the attached cells.

Ethics Committee Approval: Since this study is a cell line study, ethics committee approval has not been obtained.

Author Contributions: Concept - G.I.G., T.C., C.K.; Data Collection - G.I.G; Data Analysis and/or Interpretation - G.I.G., T.C., C.K.; Writing G.I.G., T.C., C.K.

Conflict of Interest: The authors have no conflict of interest to declare.

Financial Disclosure: The authors declared that this study has received no financial support

Etik Komite Onayı: Bu çalışma hücre kültürü çalışması olduğu için etik kurul onayı alınmamıştır.

Hakem Değerlendirmesi: Dış bağımsız.

Yazar Katkıları: Çalışma Konsepti - G.I.G., T.C., C.K.; Veri Toplama - G.I.G.; Veri Analizi/Yorumlama - G.I.G., T.C., C.K.; Yazma - G.I.G., T.C., C.K.

Çıkar Çatışması: Yazarlar çıkar çatışması bildirmemişlerdir.

Finansal Destek: Yazarlar bu çalışmada finansal destek almadıklarını beyan etmişlerdir. 


\section{REFERENCES}

1. Le Guéhennec L, Soueidan A, Layrolle P, Amouriq Y. Surface treatments of titanium dental implants for rapid osseointegration. Dental Materials 2007; 23: 844-54. [CrossRef]

2. Osman RB, Swain M V. A Critical Review of Dental Implant Materials with an Emphasis on Titanium versus Zirconia. Materials (Basel) 2015; 8: 932-58. [CrossRef]

3. Barfeie A, Wilson J, Rees J. Implant surface characteristics and their effect on osseointegration. British Dental Journal 2015; 218: 9. [CrossRef]

4. Hayakawa T, Yoshinari M, Nemoto K, Wolke JGC, Jansen JA. Effect of surface roughness and calcium phosphate coating on the implant/bone response. Clin Oral Implants Res 2000; 11: 296-304. [CrossRef]

5. García AJ, Gallant ND. Stick and grip: Measurement systems and quantitative analyses of integrin-mediated cell adhesion strength. Cell Biochemistry and Biophysics 2003; 39: 61-73. [CrossRef]

6. Khalili AA, Ahmad MR. A Review of cell adhesion studies for biomedical and biological applications. International Journal of Molecular Sciences 2015; 16: 18149-84. [CrossRef]

7. Gundogan GI. A simple and inexpensive method for evaluation of in vitro cell adhesion on screws. Cytotechnology 2020; 72: 847-54. [CrossRef]

8. Tanaka N, Moriguchi H, Sato A, Kawai T, Shimba K, Jimbo Y, et al. Microcasting with agarose gel via degassed polydimethylsiloxane molds for repellency-guided cell patterning. RSC Adv 2016; 6: 54754-62. [CrossRef]

9. Strober W. Trypan Blue Exclusion Test of Cell Viability. Curr Protoc Immunol 2015; 111: A3.B.1-A3.B.3. [CrossRef]

10. Scudiero DA, Shoemaker RH, Paull KD, Monks A, Tierney S, Nofziger TH, et al. Evaluation of a Soluble Tetrazolium/Formazan Assay for Cell Growth and Drug Sensitivity in Culture Using Human and Other Tumor Cell Lines. Cancer Res 1988; 48: 4827-33.

11. Boyan BD, Batzer R, Kieswetter K, Liu Y, Cochran DL, Szmuckler-Moncler $\mathrm{S}$, et al. Titanium surface roughness alters responsiveness of MG63 osteoblast- like cells to $1 \mathrm{a}, 25-(\mathrm{OH}) 2 \mathrm{D} 3$. J Biomed Mater Res 1998; 39: 77-85. [CrossRef]

12. Martin JY, Schwartz Z, Hummert TW, Schraub DM, Simpson J, Lankford J, et al. Effect of titanium surface roughness on proliferation, differentiation, and protein synthesis of human osteoblastlike cells (MG63). J Biomed Mater Res 1995; 29: 389-401. [CrossRef]

13. Puleo DA, Thomas M V. Implant Surfaces. Dental Clinics of North America 2006; 50: 323-38. [CrossRef]

14. Davies JE. Understanding Peri-Implant Endosseous Healing. J Dent Educ 2003; 67: 932-49. [CrossRef]

15. Deligianni DD, Katsala N, Ladas S, Sotiropoulou D, Amedee J, Missirlis YF. Effect of surface roughness of the titanium alloy Ti-6Al-4V on human bone marrow cell response and on protein adsorption. Biomaterials 2001; 22: 41-1251. [CrossRef]

16. Kubies $D$, Himmlová L, Riedel $T$, Chánová $E$, Balík $K$, Douděrová $M$, et al. The interaction of osteoblasts with bone-implant materials: 1. The effect of physicochemical surface properties of implant materials. Physiol Res 2011; 60: 95-111. [CrossRef]
17. An N, Rausch-Fan X, Wieland M, Matejka M, Andrukhov O, Schedle A. Initial attachment, subsequent cell proliferation/viability and gene expression of epithelial cells related to attachment and wound healing in response to different titanium surfaces. Dent Mater 2012; 28: 1207-14. [CrossRef]

18. Postiglione L, Di Domenico G, Ramaglia L, Montagnani S, Salzano S, Di Meglio F, et al. Behavior of SaOS-2 cells cultured on different titanium surfaces. J Dent Res 2003; 82: 692-96. [CrossRef]

19. Rosa $\mathrm{AL}$, Beloti MM. Rat bone marrow cell response to titanium and titanium alloy with different surface roughness. Clin Oral Implants Res 2003; 14: 43-8. [CrossRef]

20. Arcelli D, Palmieri A, Pezzetti F, Brunelli G, Zollino I, Carinci F. Genetic effects of a titanium surface on osteoblasts: a meta-analysis. J Oral Sci 2007; 49: 299-309. [CrossRef]

21. Kieswetter K, Schwartz Z, Dean DD, Boyan BD. The role of implant surface characteristics in the healing of bone. Crit Rev Oral Biol Med 1996; 7: 329-45. [CrossRef]

22. Lauer G, Wiedmann-Al-Ahmad M, Otten JE, Hübner U, Schmelzeisen $\mathrm{R}$, Schilli W. The titanium surface texture effects adherence and growth of human gingival keratinocytes and human maxillar osteoblast-like cells in vitro. Biomaterials 2001; 22: 2799-809. [CrossRef]

23. Conserva E, Menini M, Ravera G, Pera P. The role of surface implant treatments on the biological behavior of SaOS-2 osteoblast-like cells. An in vitro comparative study. Clin Oral Implants Res 2013; 24: 880-9. [CrossRef]

24. Bucci-Sabattini V, Cassinelli C, Coelho PG, Minnici A, Trani A, Ehrenfest $\mathrm{DMD}$. Effect of titanium implant surface nanoroughness and calcium phosphate low impregnation on bone cell activity in vitro. Oral Surgery, Oral Med Oral Pathol Oral Radiol Endodontology 2010; 109: 217-24. [CrossRef]

25. Sammons RL, Lumbikanonda N, Gross M, Cantzler P. Comparison of osteoblast spreading on microstructured dental implant surfaces and cell behaviour in an explant model of osseointegration: A scanning electron microscopic study. Clin Oral Implants Res 2005; 16: 657-66. [CrossRef]

26. Novaes AB, Papalexiou V, Grisi MFM, Souza SSLS, Taba M, Kajiwara JK. Influence of implant microstructure on the osseointegration of immediate implants placed in periodontally infected sites: A histomorphometric study in dogs. Clin Oral Implants Res 2004; 15 : 34-43. [CrossRef]

27. Marin C, Granato R, Suzuki M, Gil JN, Piattelli A, Coelho PG. Removal Torque and Histomorphometric Evaluation of Bioceramic Grit-Blasted/Acid-Etched and Dual Acid-Etched Implant Surfaces: An Experimental Study in Dogs. J Periodontol 2008; 79: 1942-9. [CrossRef]

28. Lumbikanonda N, Sammons R. Bone Cell Attachment to Dental Implants of Different Surface Characteristics. Int J Oral Maxillofac Implant 2001; 16: 627-36. 